\title{
PERANCANGAN TATA RUANG KANTOR DIVISI DR PLANT
}

\author{
Ilham Bashirudin \\ Divisi Organization Design \& Human Capital Planning, PT. Krakatau Steel (Persero) Tbk \\ Jl. Industri No.5 Po.Box.14, Cilegon, Banten \\ Email : ilham.bashirudin@krakatau
}

\begin{abstract}
Design work place in accordance with the organization's business processes will encourage efficiency and effectiveness of the functioning of the organization in order to achieve organizational goals. The following journal discussed the design of the layout of the office (office layout) based on business processes and organization. Structuring lay out in the building PTKS DR Plant is also concerned with the health minister of the republic Indonesia Decision No. 1405 / MENKES / SK / XI / 2002 concerning the health requirements of the work environment of offices and industry as well as the Company's internal regulations. The method used is Activity relatioship chart (ARC) ARC is based on business process organsiasi when relations between units in detail can be obtained from the job description, after a calculated area of the room with the organization of the Division of DR Plant obtained that from the extensive building area of 3,297 $\mathrm{m} 2$ utilized measuring 2,478 $\mathrm{m} 2$ and there is still a vast area of $819 \mathrm{~m} 2$ which can be utilized by other units in need.
\end{abstract}

Keywords : Work Place Design, Office Lay Out, Activity Relationship Chart.

\section{PENDAHULUAN}

Keberhasilan suatu perusahaan, tidak hanya ditentukan oleh SDM saja, melainkan ada faktor lain yang perlu mendapat perhatian salah satunya yaitu lingkungan tempat kerja. Design tempat kerja yang sesuai dengan proses bisnis organisasi akan mendorong terjadinya efisiensi dan efektivitas fungsi organisasi sehingga dapat mencapai tujuan tersebut colleagues.

Salah satu tantangan dalam melakukan perancangan fasilitas khususnya untuk tempat kerja adalah cara memperhitungkan dampak yang diperoleh setelah perancangan tempat kerja dilakukan. Karena tidak seperti perancangan fasilitas manufaktur yang dapat diperhitungkan nilai dari meningkatnya produksi atau menurunnya defect produk sebagai dampak perancangan tersebut, dampak perancangan fasilitas kantor lebih kepada intangible, perlu dilakukan suatu perhitungan terhadap factor - faktor lain yang lebih tangible sehingga dapat dilakukan perhitungan yang lebih riil untuk menilai tingkat keberhasilan dari perancangan fasilitas tersebut.

\section{KAJIAN PUSTAKA \\ 2.1. Perancangan Fasilitas}

Banyak definisi tata letak pabrik yang dikemukakan oleh para ahli yang pada dasarnya adalah sama, diantaranya yaitu :

1. Tata letak pabrik (plan lay out) atau tata letak fasilitas (facilities lay out) adalah tata cara pengaturan fasilitas-fasilitas fisik pabrik guna menunjang kelancaran proses produksi (Sritomo, 2000).

2. Tata letak fasilitas adalah fungsi yang melibatkan analisa (sintesa), perencanaan dan desain dari interelasi antara pengaturan fasilitas fisik, pergerakan material, aktivitas yang dihubungkan dengan personil dan aliran informasi yang dibutuhkan untuk mencapai performan optimum dalam rentang aktivitas yang berhubungan (James M, Apple, 1990).

Dalam melaksanakan perancangan fasilitas terdapat perbedaan antara perancangan fasilitas Kantor dan fasilitas manufaktur, dikarenakan adanya perbedaan produk dari kedua jenis tersebut. "Sebuah pabrik menghasilkan sesuatu," tulis Stephen Konz 
di Fasilitas Design. "Hal - hal ini dipindahkan dengan konveyor dan truk angkat, utilitas pabrik termasuk gas, air, udara terkompresi, pembuangan limbah, dan sejumlah besar listrik serta telepon dan jaringan komputer Sebuah kriteria tata letak adalah meminimalkan biaya transportasi."

Konz menunjukkan, bagaimanapun, bahwa mandat dari kantor bisnis adalah untuk menghasilkan informasi, baik disebarluaskan secara fisik (laporan, memo, dan dokumen lainnya), elektronik (file komputer), atau oral (telepon, tatap muka pertemuan) bentuk. "Kriteria tata letak kantor, meskipun sulit untuk dihitung, adalah minimalisasi biaya komunikasi dan memaksimalkan produktivitas karyawan," tulis Konz.

\subsection{Tata Ruang Kantor}

Salah satu faktor yang dapat menciptakan efisiensi kerja pegawai adalah penyusunan tata ruang kantor yang baik. A.S. Moenir (1983:7) menyatakan bahwa "Kantor sebagai tempat untuk bekerja seseorang dengan menggunakan peralatan seperti mesin tulis, mesin hitung, pensil/pulpen dan alat tulis lain dan perlengkapan kerja seperti meja, kursi, alamari, telepon, meja gambar dan lain - lain". Sedangkan Prajudi Atmosudirdjo dalam Ida Nuraida (2008:1) menyatakan bahwa Kantor adalah unit organisasi yang terdiri atas tempat, staf, personel, dan operasi ketata usahaan, guna membantu pimpinan.

Niken Nurnovitasari dalam Analisis Penataan Ruang Kantor Tata Usaha Dalam Mencapai Efisiensi Kerja Pegawai (2010:9), menyimpulkan bahwa tata ruang kantor adalah penyusunan perabot, peralatan dan perlengkapan kantor serta pengaturan tempat kerja yang disesuaikan dengan ruangan yang bertujuan untuk mewujudkan efisiensi kerja bagi pegawai. Tata ruang kantor tidak hanya sebatas tentang penermpatan dan penyusunan peralatan dan perlengkapan kantor saja, tetapi juga menyangkut jumlah peralatan dan perlengkapan tersebut, jumlah dan fungsi ruangan serta biaya yang diperlukan.

\subsection{Tujuan dan Tata Ruang Kantor yang Efektif}

Setiap kegiatan yang dilakukan dalam suatu organisasi atau instansi memiliki suatu tujuan. Dalam menyusun ruang untuk kerja perkantoran, ada beberapa tujuan yang hendak dicapai. Menurut The Liang Gie (2000:18:189) tujuan tersebut antara lain :

1. Pekerjaan di kantor itu dalam proses pelaksanaannya dapat menempuh jarak yang sependek mungkin.

2. Rangkaian aktivitas tata usaha dapat mengalir secara lancar.

3. Segenap ruang dipergunakan secara efisien untuk keperluan pekerjaan.

4. Kesehatan dan kepuasan kerja pegawai dapat terpelihara.

5. Pengawasan terhadap pekerjaan dapat berlangsung secara memuaskan

6. Pihak luar yang mengunjungi kantor yang bersangkutan mendapat kesan yang baik tentang organisasi itu.

7. Susunan tempat kerja dapat dipergunakan untuk berbagai pekerjaan dan mudah diubah sewaktu-waktu diperlukan.

Untuk penataan ruang kantor yang baik dan efektif, Slamet Soesanto (1995:56) menyatakan pedoman dalam penataan tersebut yaitu :

1. Menjamin terselenggaranya komunikasi dan transportasi mengalir secara garis lurus bukannya saling menyilang.

2. Sebaiknya ruang tidak dibagi menjadi ruang-ruang kecil, melainkan dibiarkan dalam ruang lebar yang terbuka sifatnya.

3. Dinging penyekat hendaknya bisa berpindah - pindah.

4. Ruangan hendaknya dihemat sebanyak mungkin tanpa mengekang tempattempat kerja individual.

5. Bagian yang memerlukan kontak dengan masyarakat seperti bagian personalia harus ditempatkan di suatu ruangan yang memduahkan hubungan dengan masyarakat. 
6. Alokasi ruangan didasarkan pada aliranaliran tugas utama yang berfungsi disekitar penyimpanan dokumen untuk bagian-bagian yang membutukan komunikasi silang dengan departemen lain harus diletakkan satu sama lain.

\subsection{Activity Relationship Chart}

Salah satu cara yang dipakai dalam melakukan merancang tata letak fasilitas adalah Activity Relationship Chart (ARC) yaitu cara sederhana dalam merencanakan tata letak fasilitas berdasarkan aliran bahan secara kualitatif yang dapat ditentukan dengan menggunakan derajat kedekatan hubungan aktivitas antara satu departemen dengan departemen lainnya, seperti dalam pengaturan suatu departemen dan fasilitas lainnya (Purnomo, 2004).

\subsection{Peraturan terkait}

\subsubsection{Keputusan Menteri Kesehatan RI}

Dalam Keputusan Menteri Kesehatan Republik Indonesia Nomor: 1405 / MENKES / SK / XI / 2002 tentang persyaratan kesehatan lingkungan kerja perkantoran dan industri. Luas ruangan Setiap karyawan mendapatkan ruang udara minimal $10 \mathrm{~m}^{3}$ / karyawan. Dengan memperhatikan tinggi ruangan minimal 2,5 $\mathrm{m}$ dari lantai, maka luas setiap karyawan minimal adalah $4 \mathrm{~m}^{2}$ /orang. Memperhatikan ketentuan mengenani K3LH (HSE) di Perusahaan mengenai standar ukuran fasilitas kerja seperti meja dan kursi, maka untuk perhitungan di buat luas setiap karyawan rata - rata $6 \mathrm{~m}^{2} /$ orang.

\subsubsection{Peraturan Internal}

Penataan tata letak fasilitas di PT Krakatau Steel (Persero) Tbk., diatur dalam Work Instruction (WI) Work Place Design dengan nomor dokumen PER / 03 / PO / 028 dimana Work Place Design dilaksanakan dengan tujuan meningkatkan efisiensi dan efektivitas organisasi berdasarkan proses bisnis perusahaan sekaligus mendukung penerapan Human Capital Management di PT. Krakatau Steel (Persero) Tbk.

\subsection{Rancang bangun gedung Direct Reduction}

Direct Reduction merupakan salah satu plant di PT. Krakatau Steel (Persero) Tbk., yang berfungsi untuk mengolah dan menghasilkan pelet sebagai salah satu bahan baku dalam pembuatan baja. Bangunan dalam hal ini gedung yang akan dibangun berlokasi di dalam plant berdekatan dengan fasilitas produksi yang dapat di lihat pada gambar 1, berdasarkan letak dari gedung yang dibangun maka perlu diperhatikan penempatan dari unit organisasi yang akan ditempatkan dalam bangunan tersebut sesuai dengan proses bisnis organisasi dan arah aliran informasi.

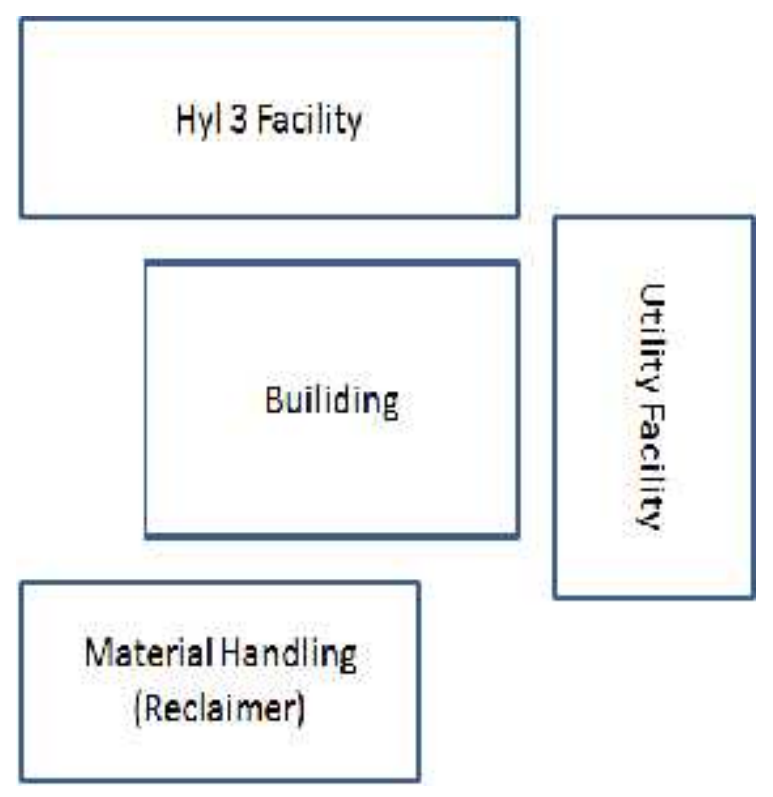

Gambar 1. Tata Letak Gedung DR.

Desain gedung Divisi DRP Gedung Iron \& Steel Making baru adalah 3 lantai dengan pembagian sabagai berikut :

1. Lantai dasar diperuntukan untuk parkir dan workshop.

2. Lantai 1 dan 2 diperuntukan untuk penempatan Divisi DRP.

Lantai 1 seluas $1.894 \mathrm{~m}^{2}$ sedangkan luas lantai 2 seluas $1.403 \mathrm{~m}^{2}$, sehingga luas gedung DR Plant total adalah $3.297 \mathrm{~m}^{2}$. Prosentase utilisasi untuk penempatan 
karyawan 92\%, sisa dipergunakan untuk jalan dan instalasi.

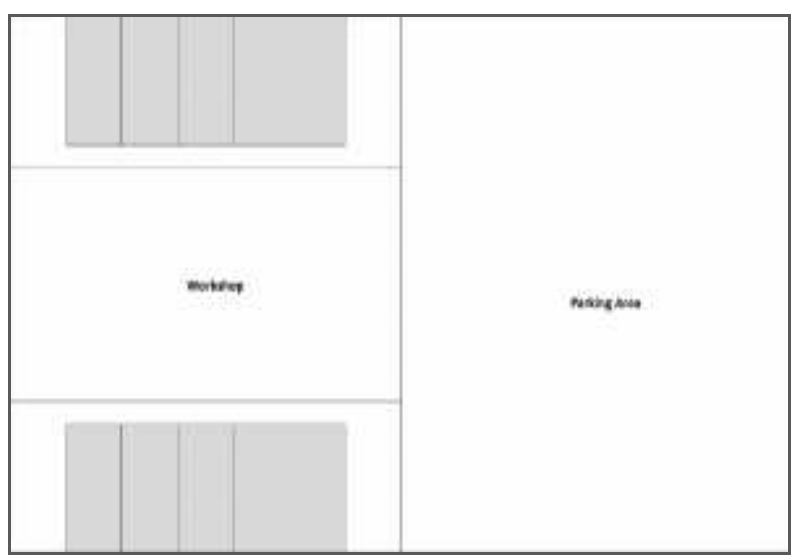

Gambar 2. Desain Lantai Dasar Gedung DR Plant.

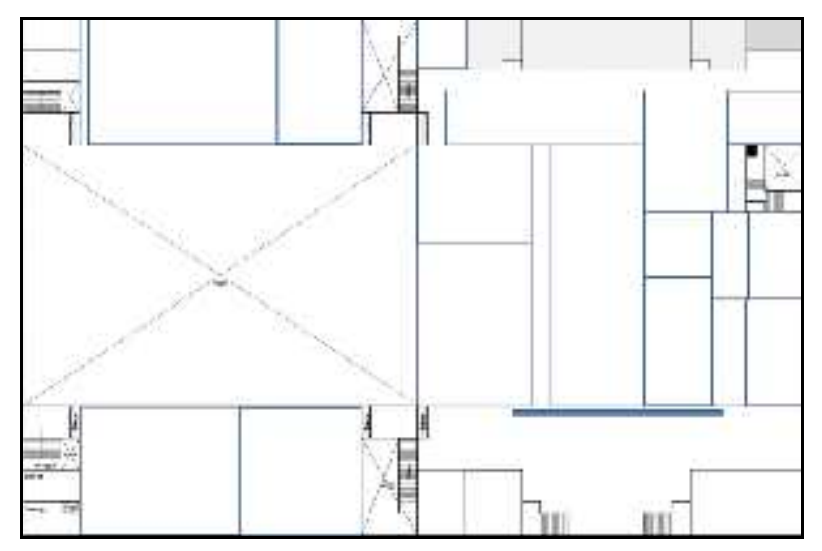

Gambar 3. Desain Lantai 1 Gedung DR Plant Luas.

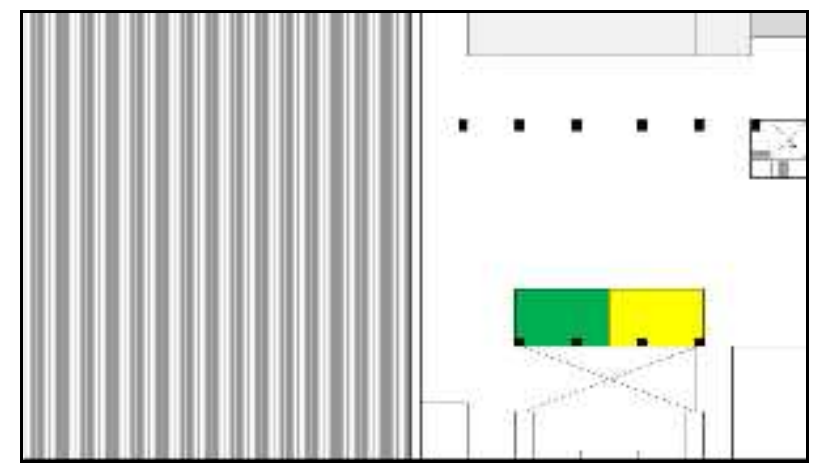

Gambar 4. Desain Lantai 1 Gedung DR Plant Luas.

\section{METODE PENELITIAN}

Tujuan utama dalam melakukan perancangan fasilitas di gedung $D R$ adalah melakukan rancangan fasilitas berdasarkan proses bisnis, sehingga untuk dapat mencapai tujuan tersebut perlu dilakukan proses seperti yang digambarkan pada flowchart di bawah ini :

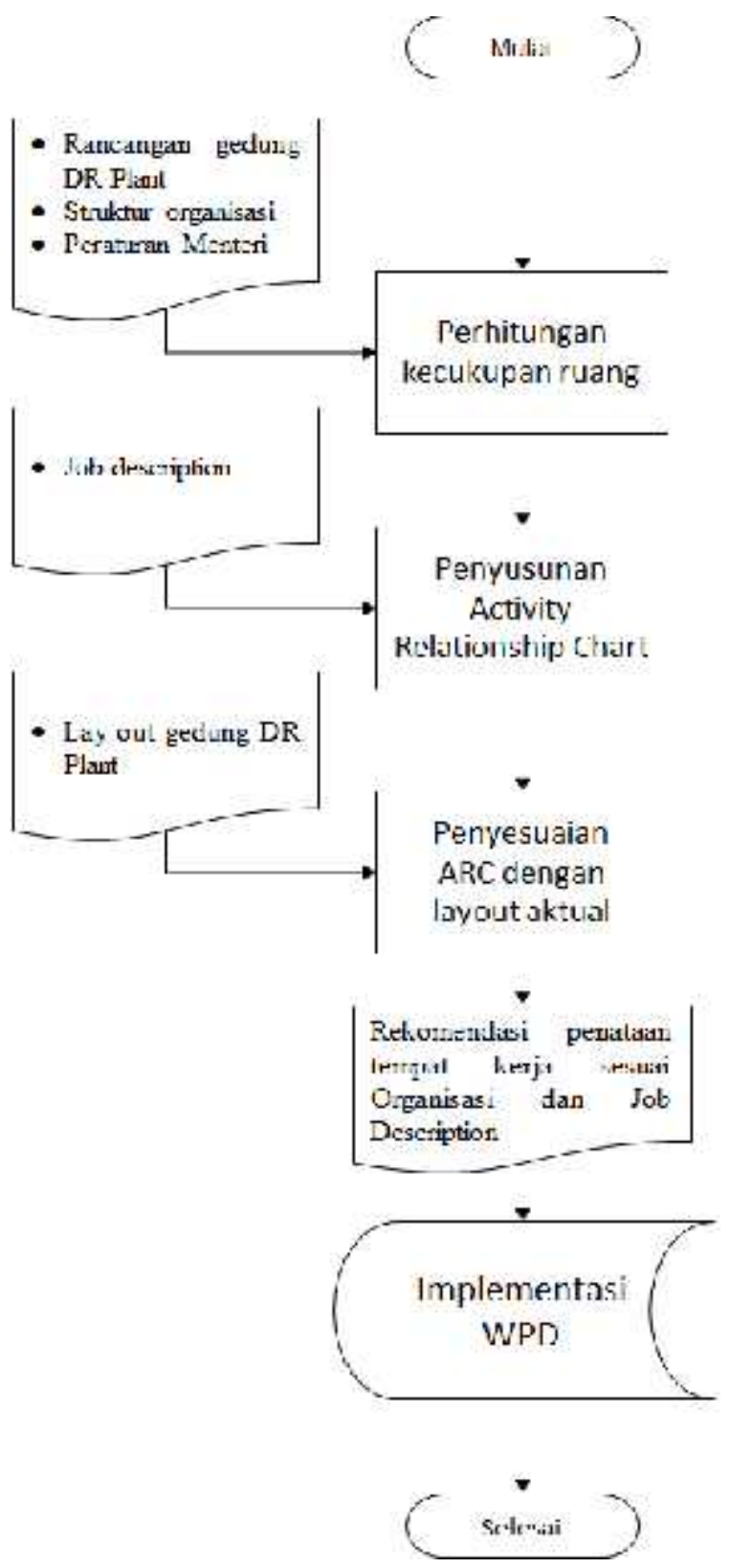

Gambar 5. Flow Chart WPD Divisi DRP.

\subsection{Prancangan Tata Letak}

Berikut adalah posisi Divisi DR Plant yang akan menempati Gedung baru adalah sebagai berikut : 
Tabel 1. Jumlah Posisi yang Akan Menempati Gedung DR Plant

\begin{tabular}{|c|c|c|}
\hline No: & Kelampak labatan & $\begin{array}{l}\text { Total } \\
\text { Personll }\end{array}$ \\
\hline 1 & Komisaris Utama & D \\
\hline 2 & Anggota Dewan Karmisaris & D \\
\hline 3 & 5taff Komisarís & D \\
\hline 4 & Direktur Utsma & D \\
\hline 5 & Anggota Diraksi & D \\
\hline 5 & Genaral Manager (AS) & D \\
\hline 7 & Manager [BS] & 2 \\
\hline 8 & Staf Setingkat General Munager \& Mansger (AF, BF) & 2 \\
\hline 9 & Superintendent (CS) & 10 \\
\hline 10 & Supervilsor (DS) & 37 \\
\hline 11 & Staff Fungsloral (Setingkat Supt, kebawah), & 173 \\
\hline 12 & Sekretarls/adminlstrasl & 9 \\
\hline & TOTAL & 233 \\
\hline
\end{tabular}

Dari struktur organisasi yang ada dan membaca job description, maka disusun Activity Relationship Chart untuk DR Plant (operasional).

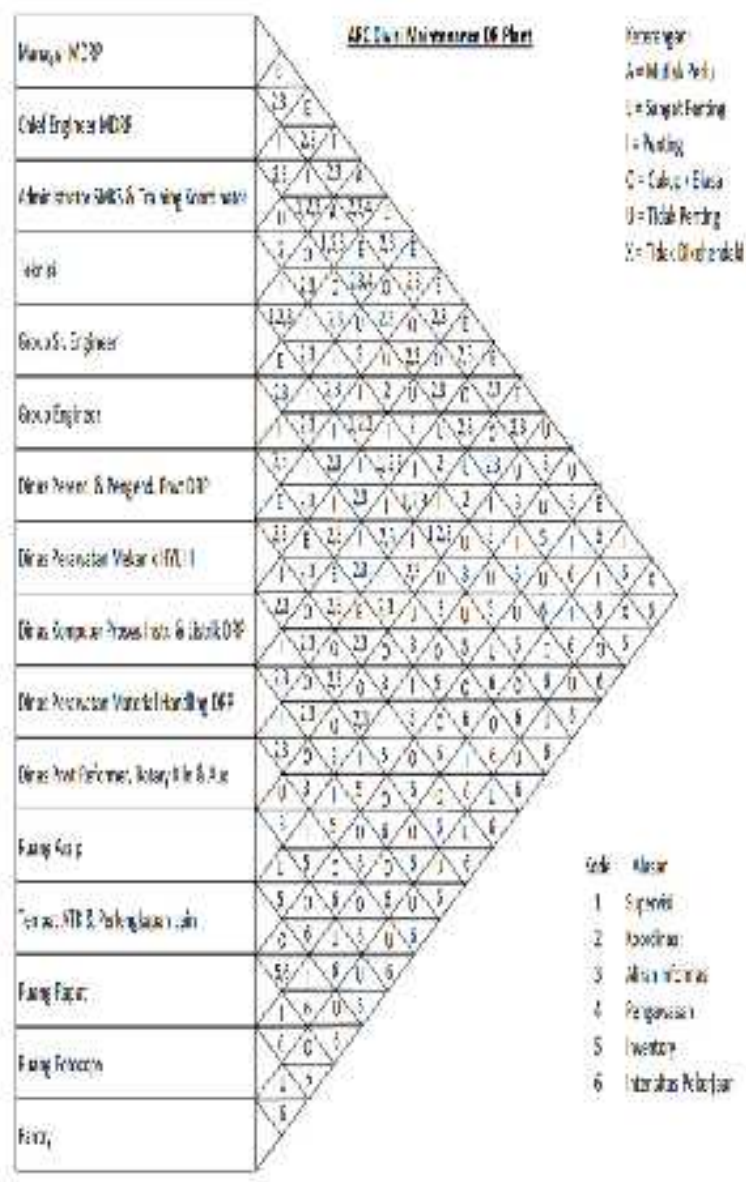

Gambar 6. ARC DR Plant (Operasional).

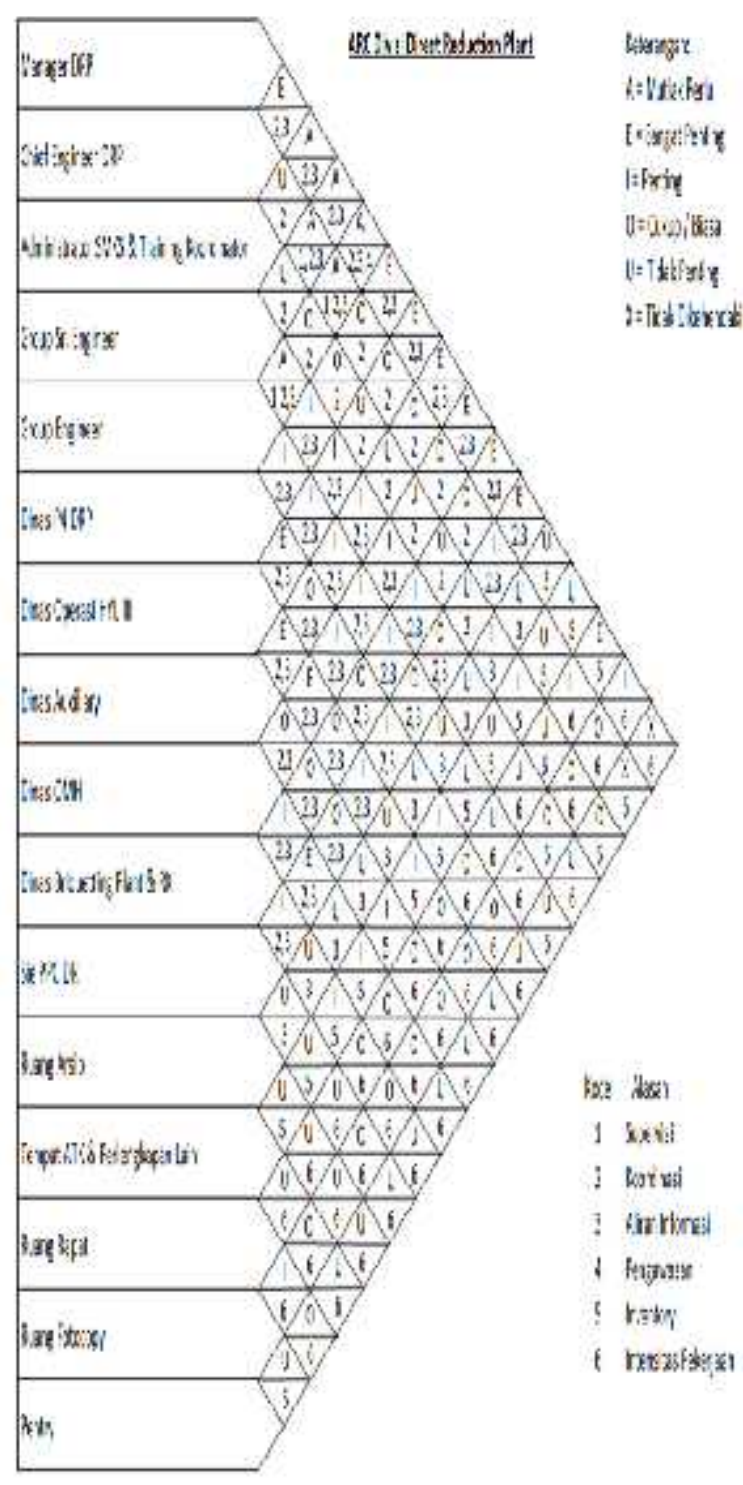

Gambar 7. ARC DR Plant (Perawatan).

\subsection{Hasil Rancangan Tata Letak}

Dari ARC yang telah disusun, dan memperhatikan layout gedung dan desain gedung DR Plant dan ketentuan yang berlaku maka disusun lay out secara detail. 


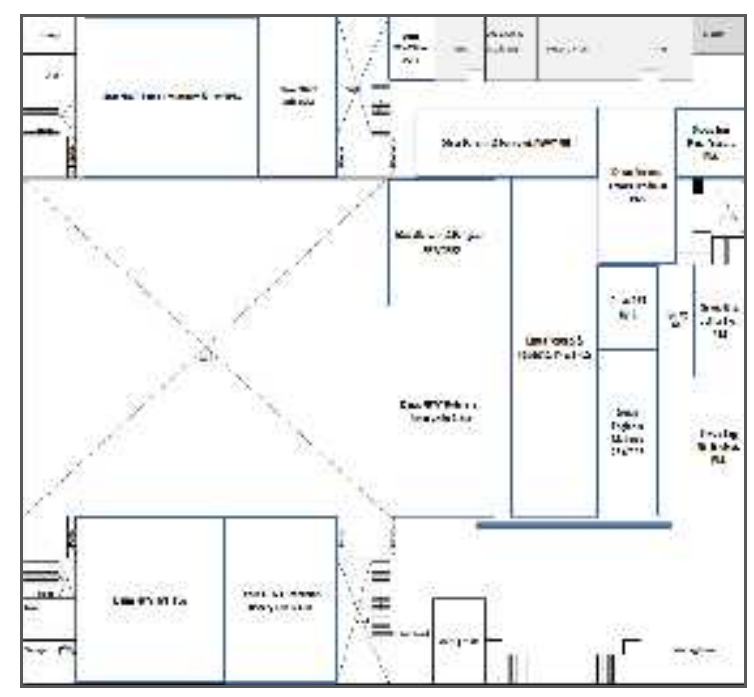

Gambar 8. Lay Out Lantai 1.

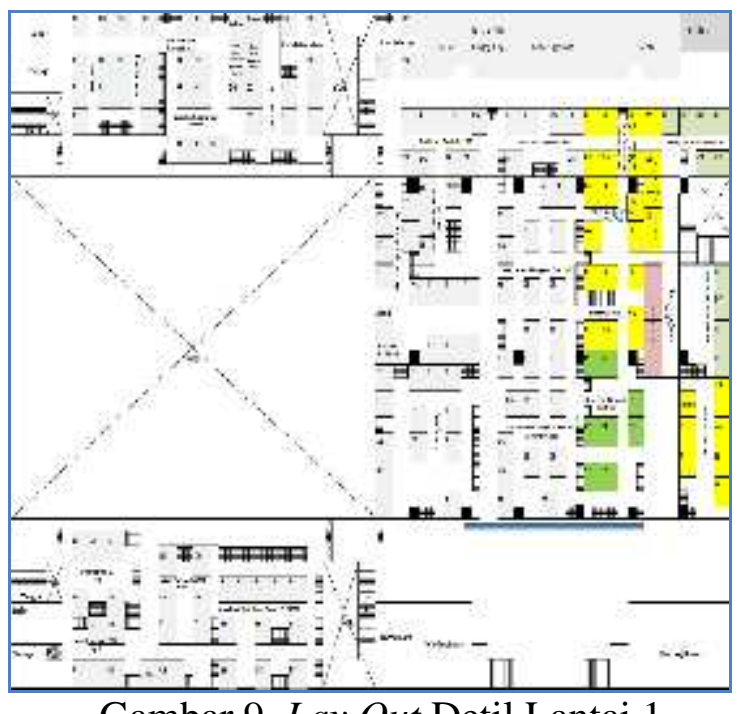

Gambar 9. Lay Out Detil Lantai 1.

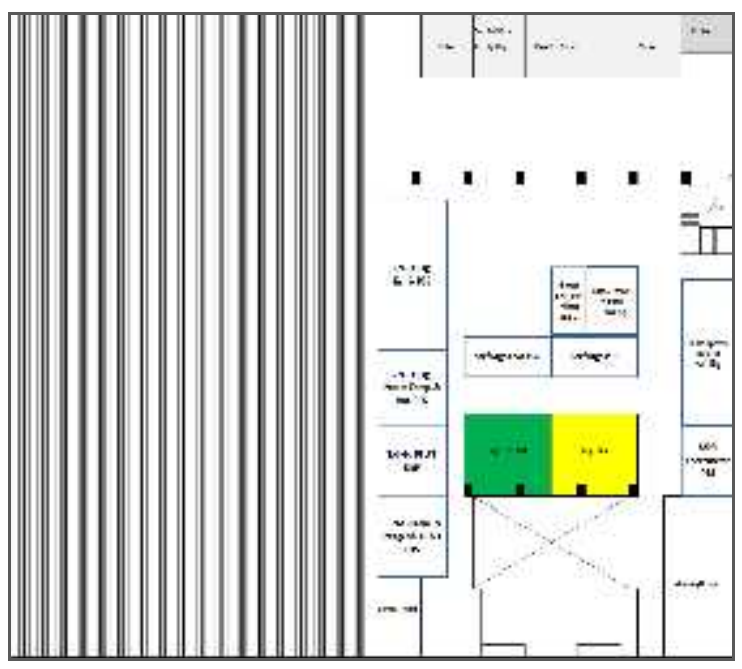

Gambar 10. Lay Out Lantai 2.

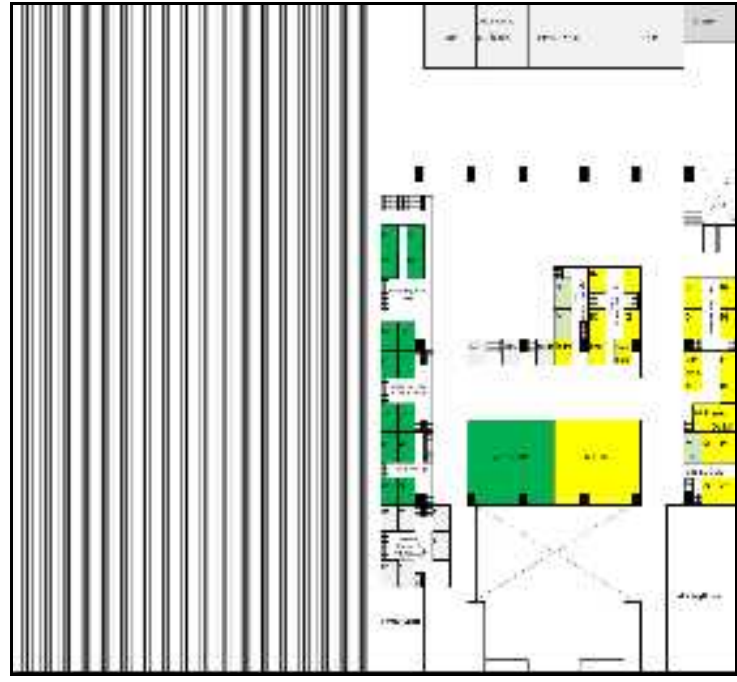

Gambar 11. Lay Out Detil Lantai 2.

\section{HASIL DAN PEMBAHASAN}

Pada perancangan tata ruang kantor Divisi DRP Gedung Iron \& Steel Making mempergunakan ARC, cara ini dipilih dikarenakan perancangan yang dilakukan pada jurnal ini sesuai dengan tujuan tata ruang kantor yaitu :

1. Memperhatikan jarak terpendek, rangkaian aktivitas dan pengawasan yang dilakukan pada saat penyusunan ARC.

2. Memperhatikan penggunaan ruang, dengan melakukan perhitungan memperhatikan penempatan lorong untuk mobilitas personil, penempatan fasilitas pendukung (lemari / filling cabinet, instalasi, dsb) dan bentuk bangunan, maka luas yang dipergunakan oleh Divisi DR Plant pada gedung ini adalah seluas $2.478 \mathrm{~m}^{2}$. Dengan rincian sebagai berikut :

a. Lantai 1 dipergunakan ruangan seluas $1.894 \quad \mathrm{~m}^{2} \quad$ (dipergunakan keseluruhan).

b. Lantai 2 dipergunakan ruangan seluas $584 \mathrm{~m}^{2}$ dari luas ruangan 1.403 $\mathrm{m}^{2}$ sehingga ruangan yang belum dipergunakan adalah seluas $819 \mathrm{~m}^{2}$.

3. Memperhatikan kesehatan pegawai, dengan dilakukan penyesuaian luas ruang sesuai Keputusan Menteri Kesehatan Republik Indonesia No:1405/MENKES/SK/XI/2002 tentang 
persyaratan kesehatan lingkungan kerja perkantoran dan industri.

4. Susunan tempat kerja dapat dipergunakan untuk berbagai pekerjaan dan mudah diubah sewaktu - waktu diperlukan, hal ini dapat dilihat dari penggunaan sekat :

a. Menggunakan sistim knock down.

b. Partisi tidak per karyawan namun per seksi dengan tinggi partisi $1 \mathrm{~m}$ agar pengawasan dan komunikasi antar seksi berjalan dengan lancar.

Hasil rancangan tata ruang kantor Divisi DRP Gedung Iron Steel Making, diserahkan kepada Divisi General Affair selaku eksekutor sesuai dengan Work Instruksi mengenai WPD, per tanggal.

\section{KESIMPULAN}

Work Place Design pada Gedung DR Plant merupakan tata ruang kantor, dari perancangan di atas diperoleh beberapa manfaat sebagai berikut :

1. Penataan tata letak Divisi DR Plant selaras dengan peraturan yang berlaku baik peraturan yang bersifat Eksternal maupun Internal.

2. Work Place Design pada Gedung DR Plant sesuai dengan tujuan dan pedoman tata ruang kantor.

3. Penataan tata ruang kantor sesuai dengan Struktur Organisasi yang berlaku dan proses bisnis organisasi tersebut.

4. Diperoleh perhitungan luas gedung yang dapat ditempati dan luas area yang masih dapat dimanfaatkan.

\section{DAFTAR PUSTAKA}

Apple, J. Tata Letak Pabrik dan Pemindahan Bahan.(Edisi Ketiga ed.). Bandung: Institut Teknologi Bandung, 1990.

Nurnovitasari, Niken. Analisis Penataan Ruang Kantor Tata Usaha Dalam Mencapai Efisiensi Kerja Pegawai. Surakarta : Universitas Sebelas Maret, 2010.

PT.Krakatau Steel (Persero) Tbk. Struktur Organisasi Divisi Direct Reduction Plant, 2013.

PT.Krakatau Steel (Persero) Tbk. Work Instruction : Work Place Design, 2013.

Purnomo, H. Perencanaan dan Perancangan Fasilitas.Yogyakarta: Graha Ilmu, 2004.

Republik Indonesia. Keputusan Menteri Kesehatan Republik Indonesia No : 1405 / MENKES /SK / XI / 2002 tentang Persyaratan Kesehatan Lingkungan Kerja Perkantoran dan Industry, 2002.

Wignjosoebroto, Sritomo. Tata Letak Pabrik dan Pemindahan Bahan, Guna Widya, Surabaya, 2003. 


\section{Lampiran}
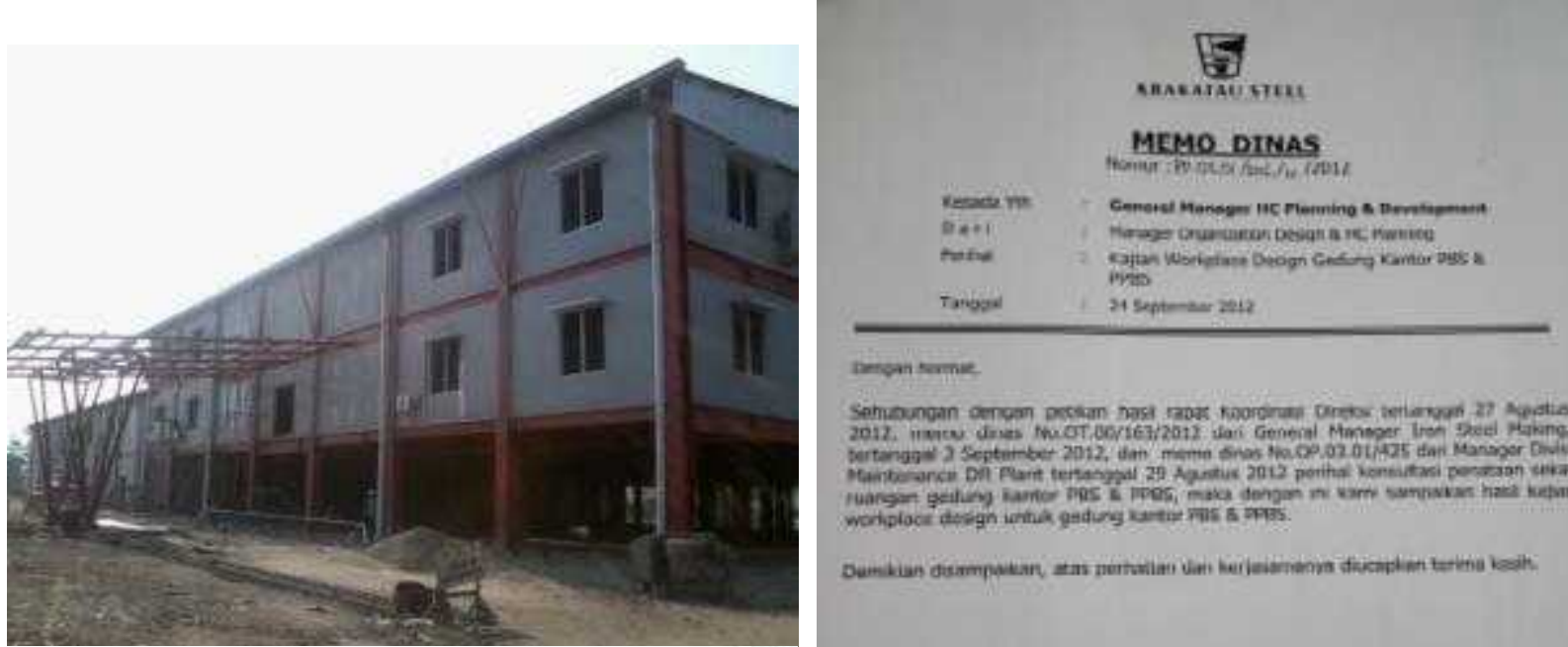

netson sermic:

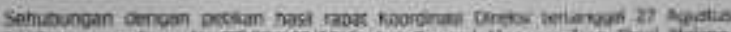

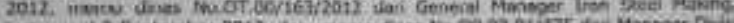

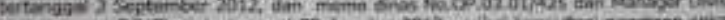

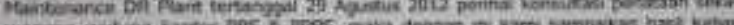

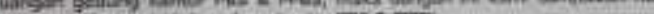

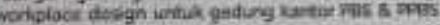

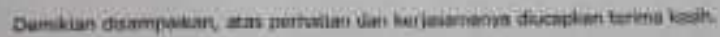

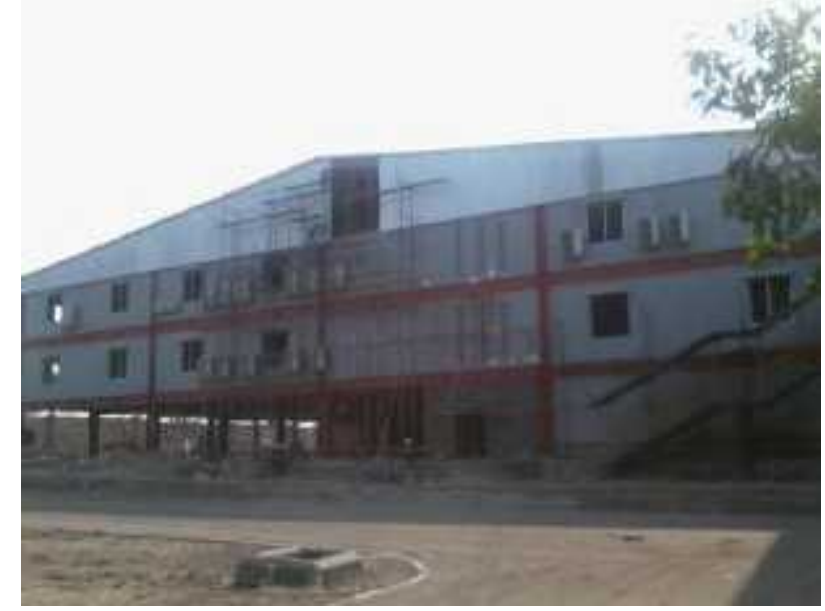

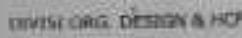

Stwor

ikervinimestios

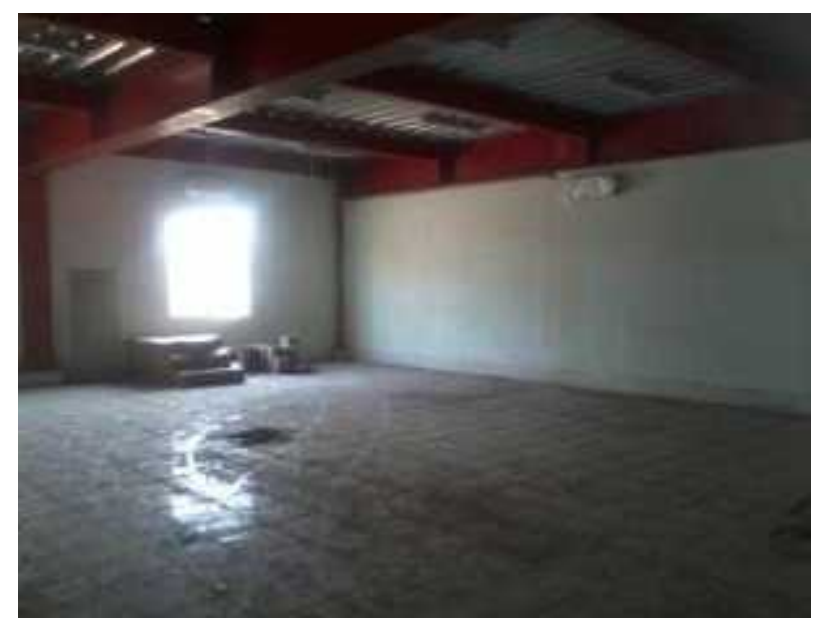

KAIAN WONVPACE DESGK GEUUKG TESANTOEAN Pas \& PPES

Taxinas 1

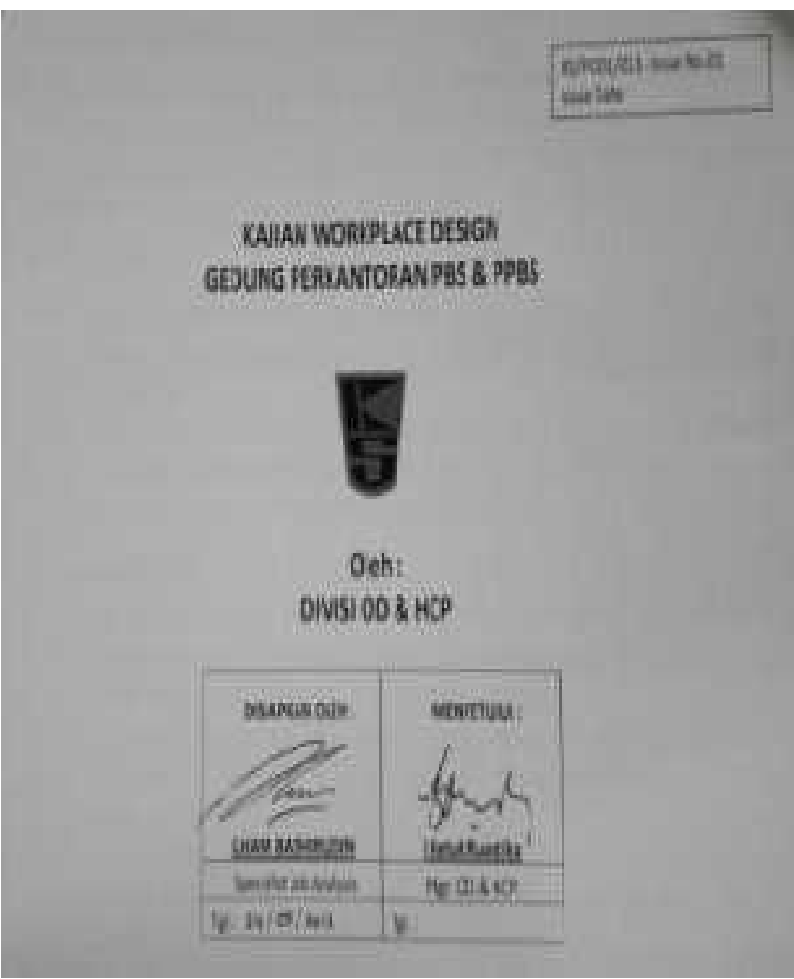



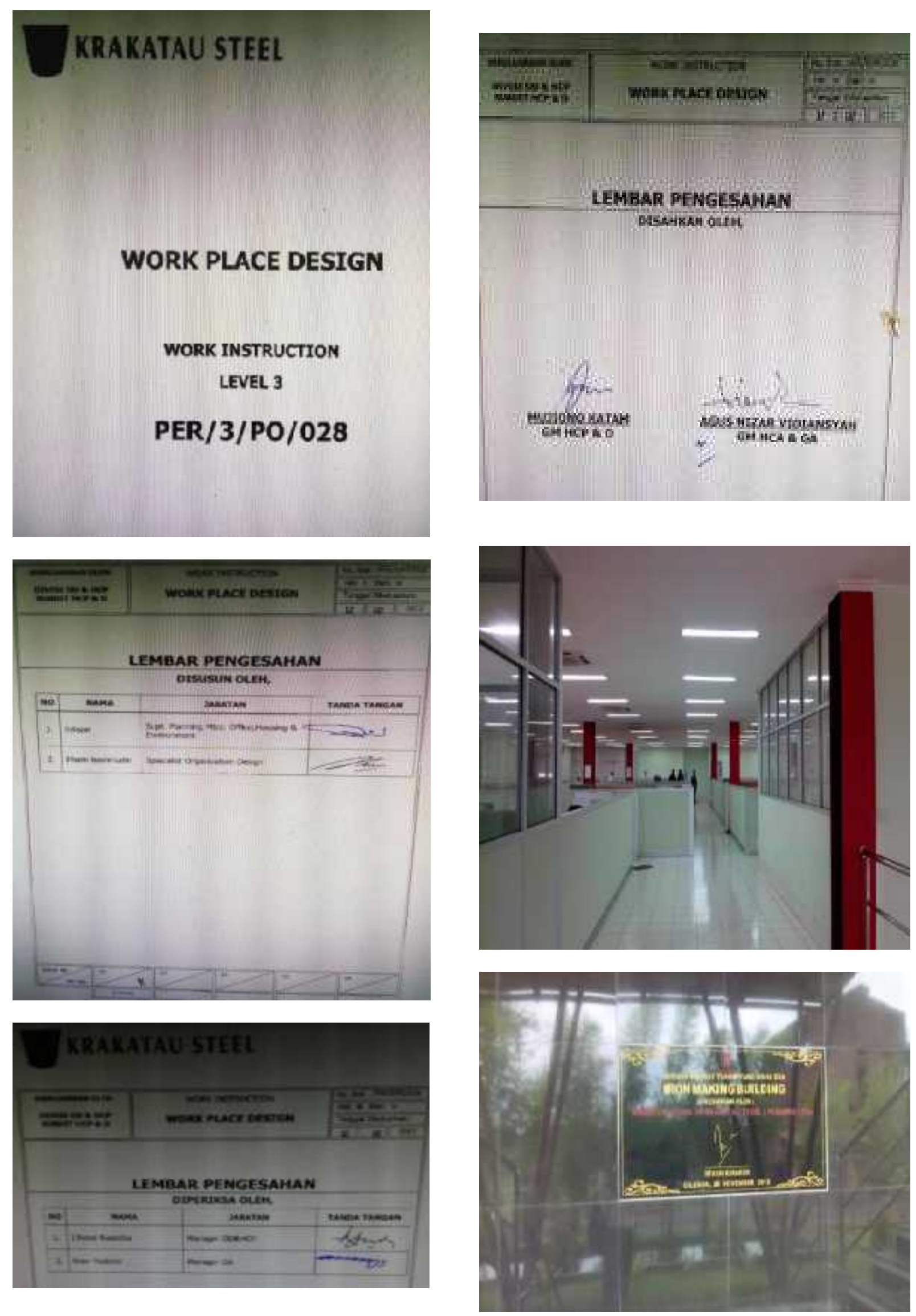

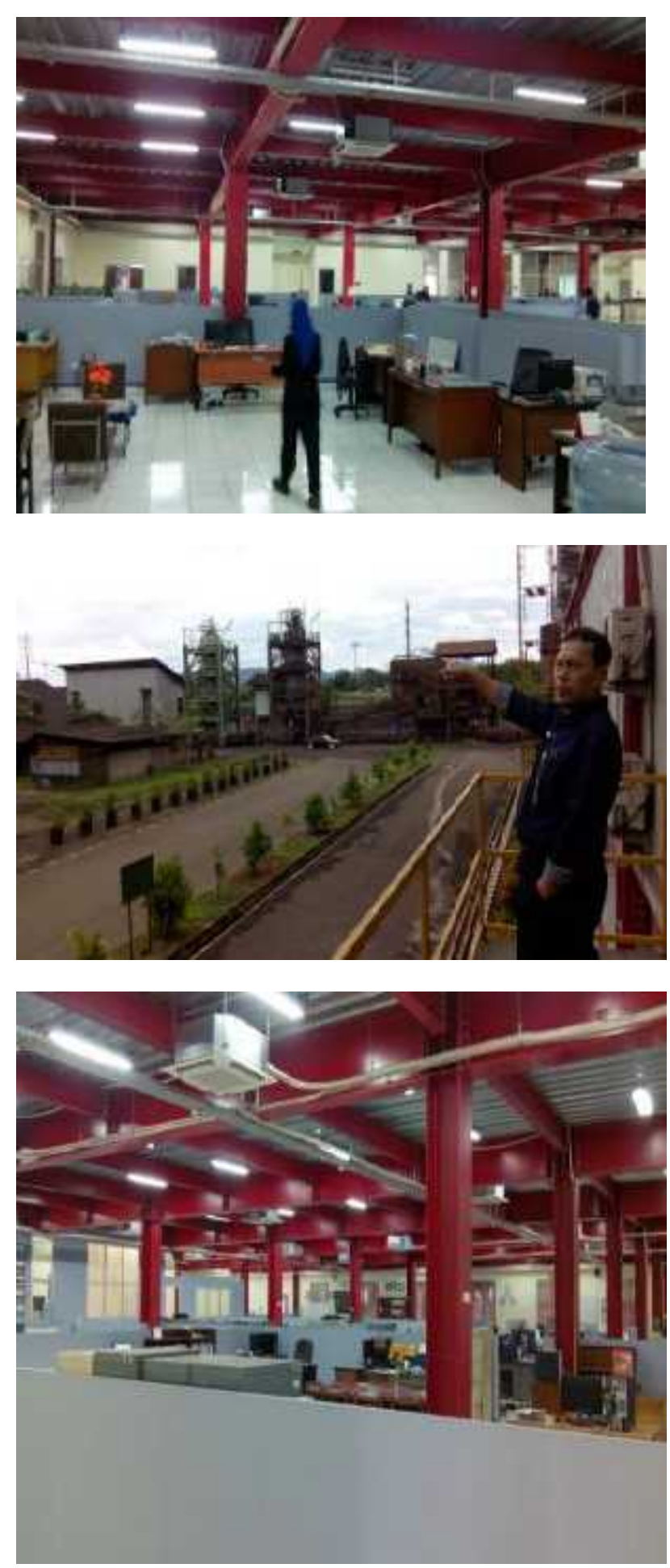